\begin{tabular}{cc} 
LOSARI: Jurnal Pengabdian Kepada Masyarakat \\
http://ojs.losari.or.id/index.php/losari \\
Volume 3 I Nomor 2 I Desember | 2021 \\
e-ISSN: 2684-8678 dan p-ISSN: 2684-9887 \\
\hline
\end{tabular}

\title{
Pendampingan Mahasiswa PPL dalam Pengembangan Media dan Strategi Pembelajaran di Masa Pandemi Covid-19
}

\section{Ruth Megawati ${ }^{{ }^{*}}$}

\author{
Keywords: \\ Pendampingan, \\ Pengembangan Media Ajar, \\ Strategi Pembelajaran
}

\section{Corespondensi Author}

${ }^{1 *}$ Pendidikan Biologi, Universitas

Cenderawasih

Jl. Poros Abepura-Sentani, Heram,

Kota Jayapura

Email: ruthmegawati@yahoo.com

\begin{abstract}
Abstrak. Kegiatan pengabdian ini dilakukan dengan tujuan untuk: (1). Meningkatkan kemampuan mahasiswa PPL dalam menyiapkan media pembelajaran disaat pembelajaran daring dan luring; (2). Meningkatkan kemampuan mahasiswa PPL dalam menyusun strategi pembelajaran di saat pembelajaran daring dan luring; (3). Agar mahasiswa memiliki kemampuan dalam menganalisis dan memilih strategi dan model pembelajaran yang tepat sesuai materi pembelajaran. Metode pelaksanaan yaitu dilakukan dengan 4 tahapan, yaitu perencanaan, perancangan, pengembangan hingga uji coba terbatas. Pembimbingan dan pendampingan yang dilakukan secara teknis dilapangan untuk setiap pengembangan media maupun RPP (Rencana Pelaksanaan Pembelajaran) yaitu melakukan pembimbingan daring sebanyak $3 \mathrm{kali}$, dan memberikan pendampingan 2 kali secara luring. RPP yang dibuat sebanyak 5 RPP. Hal-hal yang dilakukan saat daring yaitu memberikan arahan bagaimana menganalisis kurikulum hingga menyiapkan perangkat pengajaran. Selanjutnya pendampingan secara daring dilakukan guna melihat proses perencanaan dari hasil analisis yang telah dilakukan. Hasil yang didapatkan menunjukkan (1). Kemampuan mahasiswa PPL dalam menyiapkan media pembelajaran disaat pembelajaran daring dan luring berada pada kategori tinggi (2). kemampuan mahasiswa PPL Menyusun strategi pembelajaran di saat pembelajaran daring dan luring juga berada pada kategori tinggi, (3). Kemampuan mahasiswa PPL memilih strategi dan media pembelajaran yang tepat sesuai materi pembelajaran sudah baik.
\end{abstract}

(i) This work is licensed under a Creative Commons Attribution

4.0 International License

\section{Pendahuluan}

Peraturan menteri pendidikan nomor 41 tahun 2007 mengenai standar proses untuk satuan pendidikan dasar dan menengah diuraikan bahwa pembelajaran adalah proses interaksi peserta didik dengan guru dan sumber belajar pada suatu lingkungan belajar. proses pembelajaran ini perlu direncanakan, dilaksanakan, dinilai dan diawasi. namun sejak merebaknya pademi covid-19, dunia pendidikan mengalami perubahan proses pembelajaran. perubahan proses pembelajaran dari pembelajaran tatap muka langsung berubah menjadi pembelajaran jarak jauh merupakan dampak dari pandemic covid-19 yang terjadi di seluruh dunia. indonesiapun sudah mengeluatkan surat keputusan tahun 2020 yang diprakarsai oleh 4 menteri (kemendikbud, kemenag, kemenkes, 
dan kemendagri) tentang panduan penyelenggaraan pembelajaran pada tahun ajaran 2020 / 2021 dan tahun akademik 2020/2021 di masa pandemic covid-19. di mana salah satu poinnya yaitu pembatasan pembelajaran berdasarkan zonasi penyebaran covid-19 (merah, orange dan hijau). pembelajaran pun dilakukan secara virtual yang dikenal dengan istilah pembelajaran jarak jauh (PJJ).

Dampak pandemi ini juga memberikan dua istilah belajar yan trend dilakukan saat ini yaitu pembelajaran daring (dalam jaringan) dan pembelajaran luring (luar jaringan). Namun selama pandemic covid-19 apalagi untuk zona merah, dan orange pemerintah mewajibkan untuk melakukan pembelajaran daring. sehingga hal ini saat berdampak pada proses pembelajaran, baik itu bagi guru maupun bagi peserta didik. mau tidak mau pelaksana pendidikan dipaksa untuk beradaptasi dengan keadaan tersebut dimana pembelajaran tetap dilakukan dengan tidak mengabaikan keadaan yang masih dilanda pandemic covid-19.

Menyikapi kondisi tersebut, guru sebagai ujung tombak pelaksana kegiatan pembelajaran dituntut untuk lebih kreatif dan inovatif meramu proses pembelajaran agar tujuan pembelajaran tetap tercapai ditengah giatnya proses pjj. guru harus memiliki kemauan dan kompetensi untuk dapat berkreasi dan berinovasi dalam mensetting pembelajaran agar tujuan tetap tercapai. salah satu hal yang paling penting dilakukan saat pembelajaran daring yaitu media ajar. media ajar membantu guru untuk mengajar dalam hal penyampaian materi / pesan, agar memudahkan transfer informasi kepada peserta didik. jangankan disaat pembelajaran daring, dalam pembelajaran luringpun media dapat membantu guru dalam menjelaskan materi menjadi lebih sederhana dan mudah untuk dipahami. hal ini berarti bahwa keberadaan media pembelajaran memberikan makna dalam proses pembelajaran. dengan adanya media, guru terbantu untuk mentrasfer ilmu (pesan) dalam hal ini tujuan pembelajaran kepada pebelajar. dengan demikian media ajar bukan hanya sekedar pelengkap dalam proses pembelajaran tetapi sastu kesatuan yang utuh dan terintegrasi dengan strategi pembelajaran yang direncanakan oleh guru saat mengajar. konsep inipun yang harus diketahui oleh mahasiswa ppl khususnya pada program studi pendidikan biologi, universitas cenderawasih sebagai bekal dalam mempersiapkan diri menjadi guru nantinya. dimana penggunaan media merupakan hal penting dalam proses pembelajaran.

Proses pembelajaran merupakan suatu alur pembelajaran yang disetting oleh guru guna mencapai tujuan pembelajaran yang diharapkan. apalagi disaat pandemi covid-19 ini, guru harus dapat mensetting proses pembelajaran baik secara luring maupun secara daring. seperti yang telah dikemukakan sebelumnya bahwa dalam proses pembelajaran media bukan hanya sebagai pelengkap, tetapi merupakan satu kesatuan yang utuh atau bersinergi dengan strategi pembelajaran untuk mencapai tujuan. strategi pembelajaran perlu dirancang sedemikian rupa agar benar-benar dapat dilaksanakan serta sesuai dengan materi yang akan diajarkan. pemilihan strategi dengan penggunaan media ajar yang tepat sesuai materi untuk mencapai tujuan pembelajaran memerlukan analisis kebutuhan agar tepat guna. hal inilah masih menimbulkan kebingungan bagi mahasiswa untuk memilih media yang tepat dengan strategi mengajar yang cocok untuk diterapkan dalam mengajarkan suatu materi ajar. hal inilah yang menjadi latar belakang pelaksanaan kegiatan pengabdian ini. yaitu memberikan pembimbingan secara langsung selama masa PPL mahasiswa Program Studi Pendidikan Biologi, Universitas Cenderawasih. dengan memberikan pembimbingan secara intensif dan langsung mempraktekkannya, diharapkan mahasiswa dapat menanamkan konsep sekaligus mengimplementasikannya di dunia kerja kelak sebagai seorang guru.

\section{- Rumusan Masalah}

Berdasarkan analisis situasi yang dipaparkan diatas, maka rumusan masalah yang diangkat pada pengabdian kali ini yaitu:

1. Bagaimanakah kemampuan mahasiswa PPL dalam menyiapkan media pembelajaran disaat pembelajaran daring dan luring?

2. Bagaimanakah kemampuan mahasiswa PPL menyusun strategi pembelajaran disaat pembelajaran daring dan luring?

3. Bagaimanakah kemampuan mahasiswa PPL memilih strategi dan model pembelajaran yang tepat sesuai materi pembelajaran?

- Tujuan Kegiatan

Setelah kegiatan pengabdian ini diharapkan mahasiswa PPL dapat:

1. memiliki kemampuan dalam 
menyiapkan media pembelajaran di saat pembelajaran daring dan luring.

2. memiliki kemampuan dalam menyusun strategi pembelajaran di saat pembelajaran daring dan luring.

3. memiliki kemmpuan dalam menganalisis dan memilih strategi dan model pembelajaran yang tepat sesuai materi pembelajaran.

\section{Metode}

\section{Pemecahan masalah}

Guna mencapai tujuan yang dikemukakan di atas, maka Langkah yang dilakukan adalah memberikan pembimbingan atau pendampingan langsung kepada mahasiswa PPL dalam hal pengembangan media ajar dan pemilihan strategi pengajaran yang tepat sesuai dengan materi yang akan diajarkan. Pembimbingan atau pendampingan ini dilakukan secara intensif mulai dari perencanaan, persiapan hingga uji coba untuk mendapatkan produk atau hasil yang maksimal

\section{Realisasi pemecahan masalah}

Realisasi dari pemecahan masalah yang diangkat yaitu dari keterlaksanaan kegiatan pengabdian ini yang tampak dari peningkatan pemahaman mahasiswa tentang pengembangan media ajar sekaligus bagaimana memilih strategi pembelajan yang tepat sesuai dengan materi yang akan diajarkan dengan menggunakan angket, yang nantinya akan dijelaskan secara rinci pada hasil pengabdian. Selanjutnya hasil angket untuk menentukan peningkatan pemahaman mahasiswa PPL akan dikonfirmasi dengan tabel kriteria penskoran dibawah ini:

\section{Tabel 1. Kriteria interpretasis skor perolehan angket}

\begin{tabular}{|c|c|}
\hline Presentase & Kriteria \\
\hline $71 \%-100 \%$ & Sangat Tinggi \\
\hline $51 \%-70 \%$ & Tinggi \\
\hline $31 \%-50 \%$ & Cukup Tinggi \\
\hline $21 \%-30 \%$ & Baik \\
\hline $11--20 \%$ & Cukup \\
\hline $0 \%-10 \%$ & Kurang \\
\hline
\end{tabular}

Dimodifikasi_Riduwan, 2010

\section{Sasaran kegiatan}

Berdasarkan masalah yang diangkat maka sasaran dari pengabdian ini adalah mahasiswa yang melakukan PPL Tahun akademik 2020/2021 dalam hal ini mahasiswa bimbingan PPL sebanyak 3 orang. Hal ini dianggap cocok karena melihat masalah yang diangkat dalam kesiapan mahasiswa sebelum terjun didunia Pendidikan sesungguhnya sebagai seoraang guru kelak.

4. Plan way (jalannya kegiatan) dibagi menjadi empat tahap yang dapat dijelaskan sebagai berikut:

a. Perencanan

Pada tahap ini yang dilakukan adalah membimbing mahasiswa dalam melakukan perencanaan melalui analisis Kurikulum, kebutuhan dan kesiapannya mahasiswa. Pembimbingan / pendampingan dilakukan sebanyak 3 kali, melalui daring, dan 2 kali melalui luring. Hal-hal yang dilakukan saat daring yaitu memberikan arahan bagaimana menganalisis kurikulum hingga menyiapkan perangkat pengajaran. Selanjutnya pendampingan secara daring dilakukan guna melihat proses perencanaan dari hasil analisis yang telah dilakukan. RPP yang dibuat sebanyak 5 RPP.

b. Perancangan

Pada tahap ini yang dilakukan untuk merancang strategi dan media yang cocok untuk materi tertentu sesuai hasil kajian dari tahap perencanaan. Pada tahap ini dilakukan secara daring saja, yaitu mengecek kesiapan mahasiswa serta membimbing jika masih ada kekurangan dari tahap ini.

c. Pengembangan

Pada tahap ini yang dilakukan adalah pendampingan untuk menghasilkan produk, dalam hal ini media serta strategi pengahajaran melalui RPP yang telah dibuat. Pendampingan dilakukan secara daring selama 1 jam untuk setiap mahasiswa

d. Uji coba terbatas

Pada tahap ini yang dilakukan adalah, menerapkan semua hasil pengembangan melalui penampilan mahasiswa didepan mahasiswa lainnya yang menjadi peserta PPL, yang selanjutnya akan dinilai melalui sebaran angket yang diberikan kepada mahasiswa.

Berikut ditampilkan flowchart tahapan pelaksanaan kegiatan pengabdian yang dilakukan: 


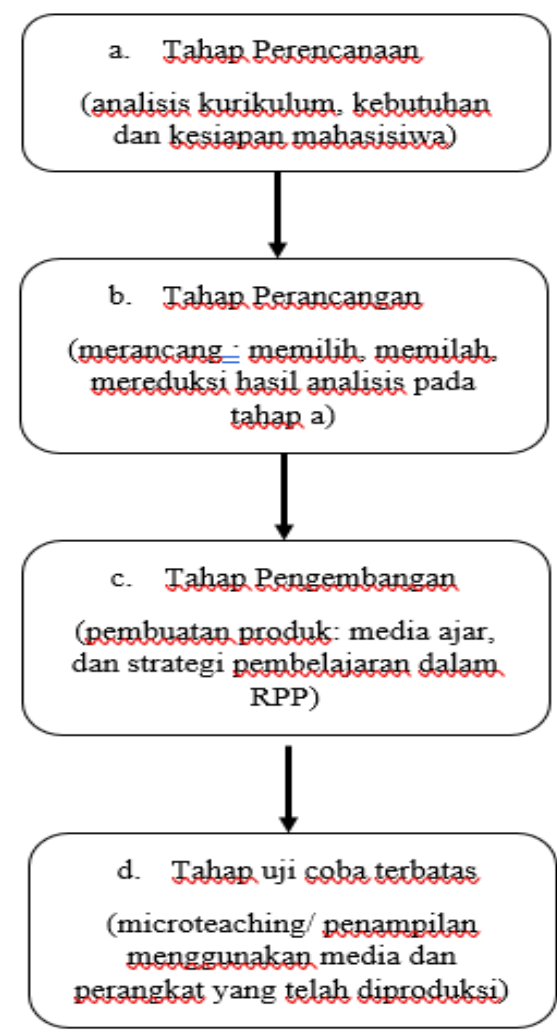

Gambar 1. Flowchart tahapan pelaksanaan kegiatan pengabdian.

\section{Hasil Dan Pembahasan}

\section{Deskripsi Pelaksanaan}

Kegiatan pengabdian (pembimbingan dan pendampingan) ini dilakukan kurang lebih 3 bulan dengan mahasiswa bimbingan sebanyak 3 orang. Pembimbingan dilakukan secara bergantian. Dengan jadwal seminggu ada 2 kali pertemuan. Baik secara daring maupun secara luring.

a. Kemampuan mahasiswa dalam pengembangan media ajar yang sesuai dengan materi yang akan diajarkan.

\section{KEMAMPUAN MAHASISWA DALAM PENGEMBANGAN MEDIAAIAR} YANG SESUAI DENGAN MATERI YANG AKAN DIAIARKAN

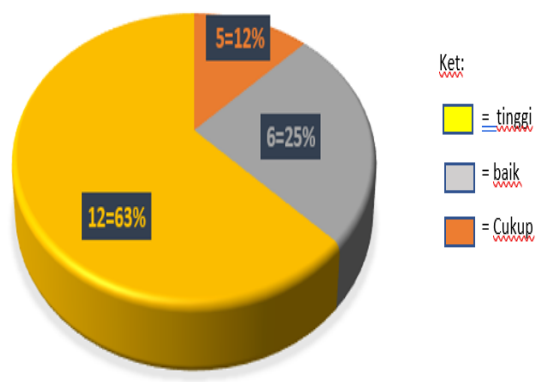

Grafik 1. Hasil angket kemampuan mahasiswa PPL dalam pengembangan media ajar
Berdasarkan grafik 1 di atas diperoleh untuk kemampuan mahasiswa dalam hal pengembangan bahan ajar yang sesuai dengan materi yang akan diajarkan sebanyak 12 frekuensi atau sebesar $63 \%$ responden yang menjawab tinggi, 6 frekuensi atau sebesar $25 \%$ yang menjawab baik dan 5 frekuensi atau sebesar $12 \%$ yang menjawan cukup. Hal ini berarti bahwa kemampuan mahasiswa dalam mengembangkan media ajar sesuai dengan materi yang akan di ajarkan sudah memadai. Adapun media yang mereka kembangkan ada dalam bentuk video pembelajaran berbasis media Camtasia, baik yang dapat diajarkan secara daring maupun yang bisa diajarkan secara luring. Pengembangan media ajar ini dilakukan seperti yang sudah dijelaskan pada plan way, mulai dari perencanaan, perancangan, pengembangan, hingga uji coba. Semua tahap ini penting untuk dilakukan guna melihat ketepatan media yang dikembangkan sesuai materi yang akan diajarkan.

Menurut Sanjaya (2011) media dapat berlaku untuk berbagai kegiatan baik dalam hal menyampaikan pesan, seperti pada dunia Pendidikan disebut sebagai media Pendidikan. Dimana media ini menjadi salah satu komponen dalam sistem pembelajaran sehingga menjadi bagian yang terintegrasi dalam proses pembelajar. Hal ini berarti bahwa untuk mencapai tujuan pembelajaran semua komponen harus dapat direncanakan dan dikembangkan dengan tepat dan sesua dengan tujuan pembelajaran. Adanya pengembangan dari media ajar ini memberikan manfaat baik bagi pendidik maupun bagi peserta didik. Arsyad (2013) mengatakan ada beberapa manfaat dari penggunaan media yaitu seperti: (1). Media dapat memperjelas penyajian pesan sehingga dapat memperlancar proses pembelajaran; (2). Media pembelajaran membantu keterbatasan indra, jarak dan waktu. Dengan adanya media objek yang terlalu besar, tidak dapat dijangkau karena waktu dan jarak dapat diatasi dengan keberadaan media yang digunakan.

\section{b. Kemampuan mahasiswa dalam Menyusun strategi pembelajaran yang sesuai dengan materi ajar.}

Berdasarkan grafik 2 diperoleh sebanyak 12 frekuensi atau sebesar $67 \%$ responden menjawab tinggi, 6 frekuensi atau sebesar $13 \%$ menjawab baik, 5 frekuensi atau sebesar $12 \%$ menjawab cukup, dan 1 frekuensi atau 8\% yang menjawab kurang. Hai ini berarti kemampuan 
mahasiswa setelah didampingi dan dibimbing saat menyusun strategi pembelajaran yang sesuai dengan bahan ajar sudah memadai, karena sebanyak $67 \%$ yang menjawab tinggi pada angket yang diberikan selama pendampingan.

Guru atau pendidik harus dapat mengelola kelas agar pembelajaran dapat dilakukan secara efektif. Pengelolaan kelas merupakan upaya yang dilakukan guru guna mewujudkan suasana belajar dan mengajar yang efektif, menyenangkan sehingga dapat mencapai tujuan pembelajaran. Hal ini diperkuat dengan adanya permendikbud nomor 81A tahun 2013 tentang implementasi kurikulum yang menyatakan bahwa kegiatan inti merupakan proses pembelajaran mencapau tujuan, yang dilakukan secara menyeluruh inspiratif, menyenangkan dan memotivasi peserta didik. Berdasarkan hal inilah guru sebagai motivator sekaligus ujung tombak dalam proses pembelajaran harus mampu berkreasi dalam menentukan strategi pembelajaran yang tepat. Agar kebutuhan dalam proses pembelajaran dapat terpenuhi dengan baik. Menurut Abdullah (2019) Ada beberapa komponen pendukung kreativitas seperti pengetahuan dan keterampilan, bakat, lingkungan, sikap dan usaha. Semua ini baiknya dimiliki guru dalam Menyusun strategi pembelajaran yang tepat.

\section{KEMAMPUAN MAHASISWA DALAM MENYUSUN STRATEG PEMBELAIARAN YANG SESUAI DENGAN MATERI AJAR}
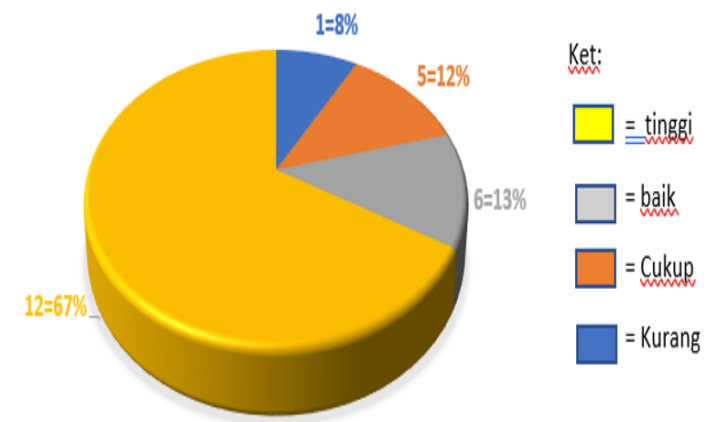

Grafik 2. Hasil angket kemampuan mahasiswa PPL dalam Menyusun strategi pembelajaran yang sesuai dengan materi ajar

Proses pembimbingan dan pendampingan yang diberikan kepada mahasiswa peserta PPL pada tahap ini yaitu membantu menganalisis strategi pembelajaran berdasarkan materi yang akan diajarkan dengan rambu-rambu penyusunan seperti (1). analisis kebutuhan, (2). analisis kedalaman materi/ cakupan pembelajaran, serta (3). analisis kondisi pemelajaran. Dengan Langkah-langkah ini mahasiswa PPL terbantu dalam penyusunan strategi yang tepat dengan materi ajar pada Rencana Pelaksanaan Pembelajaran (RPP) selanjutnya. Adanya rambu-rambu yang diberikan, menuntun mereka dalam menyusun strategi yang tepat sesuai dengan materi yang diajarkan. Adapun strategi yang mereka terapkan bermacam-macam seperti metode diskusi, domonstrasi, model-model pembelajaran koperatif seperti NHT, TGT, Picture and Picture, mencocokkan gambar dan masih banyak lagi.

\section{c. Kemampuan mahasiswa PPL memilih strategi dan media pembelajaran yang tepat sesuai materi pembelajaran}

Berdasarkan grafik 3 diperoleh sebanyak

15 frekuensi atau sebesar $63 \%$ responden menjawab tinggi, 9 frekuensi atau sebesar 37\% $\%$ menjawab baik, dan tidak ada responden yang mejawab cukup dan kurang. Ini menunjukkan bahwa kemapuan mahasiswa dalam memilih strategi dan media pembelajaran yang tepat sesuai dengan materi pembelajaran sudah memadai dilihat dari hasil angket yang diberikan memilih tinggi dan baik. Proses pemilihan strstegi dan media pembelajaran yang tepat sesuai dengan materi ajar adalah bagian yang membutuhkan analisis yang benar.

KEMAMPUAN MAHASISWA PPL

MEMILIH STRATEGI DAN MEDIA

PEMBELAJARAN YANG TEPAT SESUAI MATERI PEMBELAJARAN

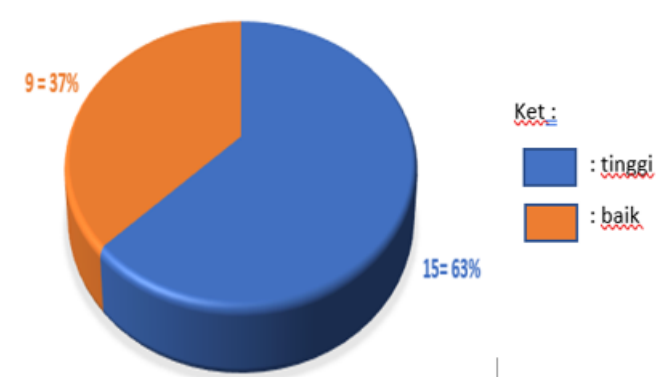

Grafik 3. hasil angket kemampuan mahasiswa PPL dalam memilih strategi dan media pembelajaran yang tepat sesuai materi pembelajaran.

Karena dengan pemaduan strategi dan media yang tepat tentunya akan memberikan dampak baik dalam proses pembelajaran guna mencapai tujuan yang diharapkan. Hilda Taba dalam Saputro, dkk (2000) menyatakan bahwa strategi pembelajaran merupakan cara-cara yang dipilih oleh guru atau pendidik dalam proses 
pembelajaran untuk memberikan kemudahan dan memfasilitasi bagi siswa menuju tercapainya tujuan pembelajaran. Yang tentunya membantu mengefektifkan proses pembelajaran. Selain itu penggunaan media yang sesuai dengan strategi yang dipilih serta materi yang akan diajarkan berperan penting dalam mencapai keefektifitasan pembelajaran.

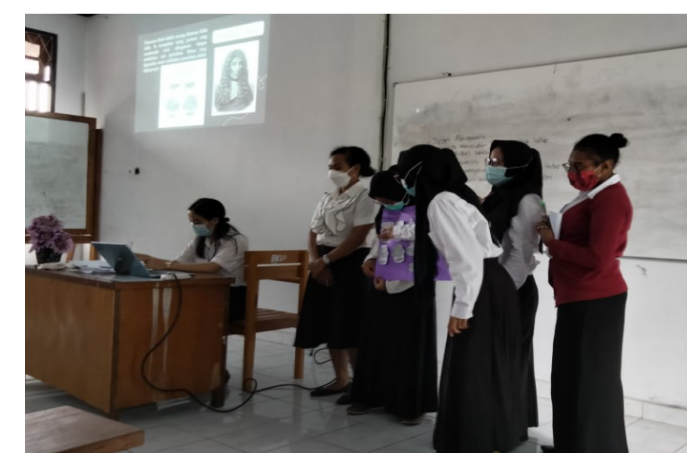

Gambar 2. Ujicoba terbatas penerapan strategi melalui model NHT dan Picture and Picture

Adapun pendampingan dan bimbingan yang diberikan kepada mahasiswa PPL pada kegiatan ini yaitu melalui Langkah Langkah berikut: (1). Bersama-sama menganalisis kedalam materi ajar, (2). Menentukan tujuan pengajaran; (3) analisis kebutuhan belajar siswa; (4). Analisis ketersediaan media ajar; (5). Analisis strategi mencakup pemilihan metode, Teknik, maupun model pembelajaran; (6). Penentuan media dan strategi dengan melakukan reduksi berdasarkan analisis kedalaman materi; (7). Menentukan media dan strategi.

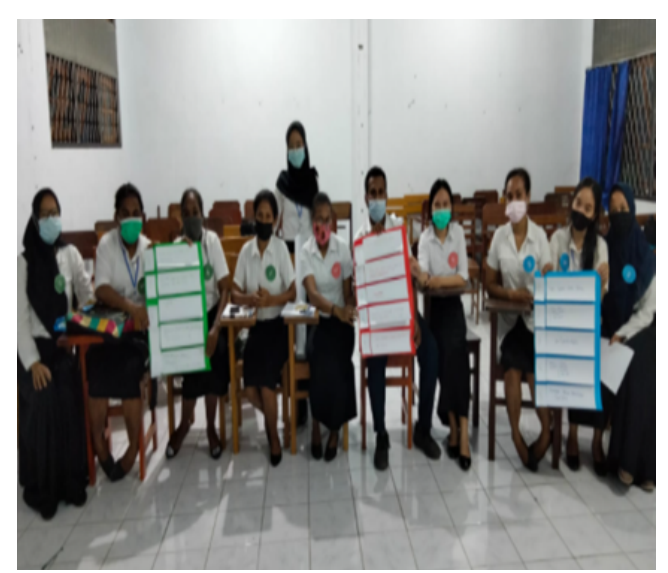

Gambar 2. Ujicoba terbatas penerapan media dan strategi pemebelajaran berbasis praktikum sederhana dan mencocokkan gambar

Kegiatan ini dilakukan secara intensif dan berkesinambungan hingga didapatkan media dan stategi yang tepat sesuai materi ajar. Langkah- langkah di atas menjadi acuan mereka untuk mengembangkan RPP selanjutnya. Hasilnya menunjukkan bahwa mahasiswa semakin kreatif dalam menentukan media dan strategi yang tepat sesuai dengan materi yang akan diajarkan. Mereka merasa lebih mudah untuk melakukan analisis karena sudah mendapatkan Langkahlangkah atau cara menentukan media dan strategi yang tepat untuk mengajarkan suatu pokok bahasan.

\section{Simpulan Dan Saran}

Berdasarkan hasil dan pembahasan maka dapat disimpulkan:

1. Kemampuan mahasiswa PPL dalam menyiapkan media pembelajaran disaat pembelajaran daring dan luring yaitu tinggi dengan presentase $63 \%$.

2. kemampuan mahasiswa PPL Menyusun strategi pembelajaran di saat pembelajaran daring dan luring yaitu tinggi dengan presentase $67 \%$.

3. Kemampuan mahasiswa PPL memilih strategi dan model pembelajaran yang tepat sesuai materi pembelajaran sudah baik dengan presentasi $63 \%$.

Saran dari kegiatan ini adalah diperlukan uji coba lapangan pada media dan perangkat yang dihasilkan, sehingga lebih mengetahui kevalidan dari media dan perangkat yang sudah dikembangkan. Karena uji coba yang sudah dilakukan hanya uji coba terbatas yang dilakukan di program studi.

\section{Daftar Rujukan}

Abdullah, R. S. (2019). Strategi Belajar Mengajar. Jakarta: Rajagrafindo Persada.

Aqib, Z. (2017). Model-model, media, dan strategi pembelajaran Kontekstual (Inovatif). Bandung: CV Utama Widya.

Arsyad, A. (2013). Media Pembelajaran. Jakarta: Rajagrafindo Persada.

Djamarah , S. B., \& Zain, A. (2014). Strategi Belajar Mengajar. Jakarta: Rineka Cipta.

Emzir. (2015). Metodologi Penelitian Pendidikan. Jakarta: Rajagrafindo Persada.

Fauzia, J. H., \& Kurniawati, F. (2020). Efektivitas program pelatihan penetapan tujuan pada siswa Sekolah Menengah 
Atas. Jurnal Psikologi Teori dan Terapan, 1-6.

Mahmudah, A., \& Pustikaningsih, A. (2019). Pengembangan Media Pembelajaran Interaktif Berbasis Lectora Inspire Pada Materi Jurnal Penyesuaian Untuk Siswa Kelas X Akuntansi Dan Keuangan Lembaga Smk Negeri 1 Tempel Tahun Ajaran 2018/2019. Jurnal Pendidikan Akuntansi Indonesia, 97-111.

Pribadi, B. (2017). Media dan Teknologi dalam Pembelajaran. Jakarta : Kencana.

Rahmawati, S., Imawati, R., \& Firmiana, M. (2017). elatihan Motivasi Bagi Siswa Kelas XI SMA dalam Mempersiapkan Diri Menghadapi Ujian Nasional. AlAzhar Indonesia Seri Humaniora, 34-40.

Riduwan. (2010). Skala Pemngukuran Variabelvariabel Penelitian. Bandung : Alfabeta.

Rima, E. W. (2016). Ragam Media Pembelajaran. Jakarta: Kata Pena.

Rohmawati, A. (2015). Efektivitas Pembelajaran. Jurnal Pendidikan Usia Dini, 15-32.

Sanjaya, W. (2015). Penelitian Pendidikan (Jenis, metode dan Prosedur). Jakarta: Prenamedia Group.

Satrianawati. (2018). Media dan Sumber Belajar - Yogyakarta: Deepublish CV Budi Utama.

Siregar, S. (2017). Metode Penelitian kuantitatif dilengkapi dengan perbandingan perhitungan manual dan SPSS. Jakarta: Alfabeta.

Sugiyono. (2017). Statistik Untuk Penelitian. Bandung : Alfabeta.

Yaumi, M. (2018). Media dan Teknologi Pembelajaran. Jakarta: Prenadamedia Group. 